„Analiza i Egzystencja” 37 (2017)

ISSN 1734-9923

DOI: 10.18276/aie.2017.37-05

ARTYKUŁY

\title{
ARTUR SZACHNIEWICZ
}

\section{CZY MONADY MAJĄ CZĘŚCI? WITKIEWICZ WOBEC MEREOLOGII JAKO ONTOLOGII*}

Słowa kluczowe: Witkiewicz, Leśniewski, mereologia, monadyzm, ontologia Keywords: Witkiewicz, Leśniewski, mereology, monads, ontology

\section{Wstęp}

Kotarbiński (2002), dokonując opisu witkiewiczowskiej kategorii Istnienia Poszczególnego zwrócił uwagę na nieredukowalną różnicę między osobnikiem rozumianym jako ciało (rozciągłość sama dla siebie) a osobnikiem pojętym jako kompleks jakości (świadomość, trwanie samo dla siebie). Witkiewicz oba te wymiary monadycznego Istnienia Poszczególnego umieszcza w ramach odrębnych opisów: odpowiednio obiektywnego i subiektywnego. Wobec tego Kotarbiński konkluduje, że słowo 'jest' użyte w zdaniu typu obiektywnego: 'x jest osobnikiem’ musi mieć inny sens, niż w zdaniu typu

* Artur Szachniewicz - doktorant w Zakładzie Ontologii Instytutu Filozofii w Uniwersytecie Jagiellońskim. Zainteresowania naukowe: ontologiczne zagadnienia filozofii umysłu, ontologia Witkiewicza, koncepcje panpsychistyczne.

Address for correspondence: Artur Szachniewicz, Department of Ontology, Faculty of Philosophy, Jagiellonian University, ul. Grodzka 52, 31-044 Kraków. E-mail: artur. szachniewicz@gmail.com.

** Dziękuję dr. Maciejowi Dombrowskiemu za uwagi i wskazówki bibliograficzne. 
subiektywnego: 'x jest kompleksem swych jakości' (Kotarbiński, 2002, s. 394). W konsekwencji takiej analizy zasadnym staje się pytanie o to, które z tych rozumień jest bardziej fundamentalne, a odpowiedź w naturalny sposób prowadzi ku określonym postaciom monizmu: materialistycznego lub idealistycznego. Z tego powodu rozstrzygnięcia Kotarbińskiego napotykają w replice Witkiewicza na obronę nieusuwalnej wieloznaczności słowa 'jest'. Jego zdaniem byt indywidualny jest a przy tym jest jeden i jest dwoisty zarazem; ta dwoistość istnienia jest bezpośrednią i nieredukowalną daną doświadczenia (Witkiewicz, 2002a, s. 408-409).

Witkiewicz był przekonany, że byt może być zrozumiany adekwatnie i w sposób niezafałszowany tylko w swojej źródłowej dwoistości, łączącej to, co mentalne i niementalne (Witkiewicz, 2002a, 2002c), a przedstawiona przez Kotarbińskiego analiza semantyczna jest efektem „logicznych tricków opartych o fałszywe stosowanie pojęć ogólnych: przedmiotu, stosunku (specjalnie całości i części) i jednoznacznego używania słowa jest" (Witkiewicz, 2002a, s. 406).

Witkacy, zwracając uwagę na pojęcia części i całości, przywołuje w przypisie pracę Leśniewskiego O podstawach matematyki. W niniejszym artykule podejmuję ten trop i rekonstruuję rozumienie logiki przez Witkiewicza oraz podkreślam różnicę w jego ocenie logiki i systemów logistyki pojętych jako dedukcyjne systemy sformalizowane (rozdział 2). Analizuję wczesne poglądy Leśniewskiego, zwracając uwagę na leżącą u ich podstaw metafizyczną koncepcję rzeczywistości. Eksponuję intuicyjny punkt wyjścia mereologii oraz staram się wskazać na te jej elementy, z powodu których Witkiewicz mógł odczytać mereologię jako ontologię (rozdział 3). Zdaniem Witkiewicza, taka ontologia była w niewystarczającym stopniu uzasadniona filozoficznie. Argumentuję przeciwko tezie, jakoby Witkiewicz uznawał mereologię za system twierdzeń o monadach (Kościuszko, 2005) (rozdział 4).

\section{Logika a logistyka w oczach Witkiewicza}

Termin 'logistyka' funkcjonuje jako historyczna nazwa dla sformalizowanych systemów logicznych. Za czasów Witkiewicza ustalony był już termin 'logika symboliczna' czy 'logika matematyczna' (logique mathématique) (Zob. Lindenbaum, Tarski, 1926). Łukasiewicz (1933) pisał wprost, że 'logika matematyczna' znaczy tyle co 'logistyka' (s. 116). Witkiewicz w swoich 
pismach nigdy jednak nie zdecydował się zastąpić tego terminu innymi, używanymi współcześnie.

Sądzę, że istnieją rzeczowe powody, dla których Witkiewicz nie używa terminu 'matematyka symboliczna', 'logika matematyczna' czy ostatecznie 'logika' w kontekstach, w których używa terminu 'logistyka'. Nie chodzi tylko o powszechne użycie symboliki i precyzję formalną systemu dedukcyjnego. Witkacy rozróżniał pojęcia kryjące się za powyższymi nazwami. Twierdził, że „nie ma jednej logistyki, tak jak była jedna logika i jest jedna matematyka” (Witkiewicz, 2014c, s. 170). Trafnie zaznaczył, że „może być wiele logistyk, zależnie od założeń pierwotnych czyli aksjomatów" (Witkiewicz, 2014c, s. 170).

W przeciwieństwie do wielości arbitralnych logistyk logika jest jedna, choć nieabsolutna. Witkiewicz rozumiał logikę jako ,narzędzie wytworzone przez pewne stwory żywe, które, w przystosowaniu się swym do otaczającego świata (...) zaczęły używać znaków" (Witkiewicz, 2014b, s. 491-492). Jego zdaniem logika tradycyjna

nie miała założeń podstawowych [aksjomatów - A.Sz.], które trzeba było dopiero explicite przyjąć - pewne jej założenia: istnienie wielości w ogóle, zasada identyczności, tj. używanie tego samego znaku w tym samym znaczeniu, a następnie istnienie pojęć, tj. znaków o pewnych znaczeniach (...) były prawie same z siebie zrozumiałe. Wynikały (...) z właściwości naszego języka, urobionego przez wieki i opartego w swych kategoriach o zasadnicze właściwości samego istnienia w ogóle (Witkiewicz, 2014c, s. 163).

Specyfika tego podejścia do logiki zasadza się na traktowaniu logiki jako nauki apriorycznej i jednocześnie opartej na powszechnych i zasadniczych formach wszelkiego istnienia. Zdaniem Witkiewicza wszystkie procesy myślowe sprowadzają się do asocjacji kompleksów jakości i ich następstw. Te zaś wyznaczone są przez ogólne warunki istnienia. Te same zasady rządzą zatem logiką i ontologią: ,nie moglibyśmy sobie wyobrazić ani innej egzystencji jak osobową w związku z ciałem wśród innych stworzeń i świata materii martwej, tak samo, jak nie moglibyśmy sobie wyobrazić innych form językowych i logicznych” (Witkiewicz, 2014c, s. 163).

Logika jako „nauka normatywna” miała zdaniem Witkiewicza ,stworzyć ogólny inwentarz stosunków zachodzących między pojęciami” (Witkiewicz, 2014c, s. 165; zob. też: Witkiewicz, 2002c, s. 314). Tak rozumianą 
logikę określał jako „narzędzie do maszyny jaką jest mowa” (Witkiewicz, 2014b, s. 492). Aprioryczny status praw logicznych miał zaś być skutkiem tego, że w jej prawach „wyrażają się t e ż [wyróżnienie - A.Sz.] zasadnicze prawa istnienia" (Witkiewicz, 2014c, s. 167).

Ze względu na nominalistyczne przekonania Witkiewicza, wszystkie 'pojęcia' logiki są dlań tylko materialnymi znakami lub kompleksami związanych asocjacyjnie jakości; „w ostateczności, rozumowania opierają się na oczywistościach danych wyobrażeniowo" (Witkiewicz, 2014c, s. 167). Na tym też zasadzał się dla niego formalny charakter logiki, który rozumiał jako „niezależny od treści” stosunek zdań (Witkiewicz, 2014b, s. 491). W zbliżony sposób Łukasiewicz (1933) opisywał praktykę współczesnej mu formalnej logiki matematycznej, która, uprawiana w nastawieniu nominalistycznym, mówi o nazwach i zdaniach traktowanych jako napisy o pewnej formie. Formalizacja zaś to zabieg gwarantujący zgodność z regułami przekształcania napisów bez odwoływania się do znaczenia tych napisów. Praktyka ta ma na celu ,sprowadzenie wszelkiej oczywistości logicznej do oczywistości wzrokowej” (Łukasiewicz, 1933, s. 119).

Można zatem uznać, że formalizm sam w sobie nie stanowił dla Witkiewicza istotnego problemu. Przeciwnie - jako nominalista odrzucający sferę abstrakcyjnych sensów (znaczeń), akceptował zasadniczo formalną naturę związków między tezami logiki. Tym, co nastawiało go krytycznie do systemów logistyki, jest nie tyle ich formalizm, co arbitralność założeń. Problematyczna jest dla niego relacja między opisywaną rzeczywistością a systemem jako całością.

W pracy O ontologicznej beznadziejności logiki... Witkacy podkreśla braki w metafizycznym ugruntowaniu logistyki. Sygnalizuje, że „nie wiadomo co kieruje przyjęciem takich a nie innych znaczków, które jakieś znaczenie (...) mieć muszą, jak i [muszą je mieć - A.Sz.] pierwsze twierdzenia [aksjomaty - A.Sz.] bo inaczej aparat taki nie dałby się stosować do rzeczywistości” (Witkiewicz, 2014d, s. 356). Jako remedium, pod nazwą ontologizacji logiki, postulował konceptualizację jej założeń w terminach metafizycznych. W praktyce rozumiał przez to, ,że konieczne zasady istnienia, konieczne pojęcia i twierdzenia, których nie przyjąć nie możemy, muszą leżeć u podstaw wyboru pierwszych znaczków i pierwszych ich połączeń" (Witkiewicz, 2014d, s. 357). Te pierwotne zasady powinny charakteryzować się pewną oczywistością i intuicyjnością. Witkacy był zdania, że jego własne poglądy łączące w punkcie wyjścia najbardziej ewidentne intuicje 
naiwnego światopoglądu oraz nauk spełniają ten wymóg - przeciwnie do założeń systemów logistyki.

Ze względu na owe założenia podejrzewał ,pozorne oderwanie logistyki od rzeczywistości" (Witkiewicz, 2014d, s. 357). Domniemanie to można interpretować dwojako: jako mówiące o ukrytej w założeniach różnych systemów logistyki autentycznej ontologicznej prawdzie, bądź też jako wyraz nieświadomości logistyki i arbitralnego postulowania treści ontologicznej. W dalszej części wywodu będę starał się pokazać, że ta druga teza znajduje większe oparcie w tekstach; że Witkiewicz odbierał system Leśniewskiego jako jeden z arbitralnych systemów ontologicznych.

\section{Mereologia a intuicje naturalnego nastawienia}

Leśniewski opublikował rezultaty swoich najwcześniejszych badań mereologicznych w 1916 roku w Moskwie. Wcześniej zajmował się zagadnieniami gramatyczno-logicznymi i metafizycznymi. Prac tych wyparł się później (Leśniewski 1927, s. 182-183), poświęcając się zagadnieniom formalno-logicznym. Począwszy od roku 1927 publikował wyniki swoich badań w Przegladzie Filozoficznym, gdzie ukazywały się w częściach do 1931 roku. Jego badania nad podstawami matematyki przyniosły efekt w postaci trzech systemów znanych jako prototetyka, ontologia i mereologia. Od 1919 roku Leśniewski wykładał na Uniwersytecie Warszawskim i, jak sam wspomina (Leśniewski, 1927), w tym okresie jego nieopublikowane wyniki były przedmiotem dyskusji.

Leśniewski traktował zespół systemów prototetyki, ontologii i mereologii jako, ,jeden z możliwych fundamentów całokształtu nauk matematycznych" (Leśniewski, 1927, s. 165). Podjął się opracowania tego zagadnienia, dążąc do wyeliminowania antynomii z podstaw matematyki. Chodziło m.in. o antynomię wywiedzioną przez Russella z teorii mnogości opracowanej przez Fregego w Grundgesetze der Arithmetik.

Frege uzupełnił swój system o aksjomat, który miał zabezpieczyć go przed antynomicznymi rozumowaniami, jednak Leśniewski zarzucał mu nieintuicyjność. Tę samą wadę wytykał aksjomatyzacji przedstawionej przez Zermela. O tej ostatniej pisał wprost, że „wprowadza do teorii mnogości szereg pozbawionych uzasadnienia intuicyjnego zakazów" (Leśniewski, 1927, s. 167). Próbom podejmowanym w celu wyeliminowania antynomii 
z podstaw matematyki zarzucał arbitralność. Ubolewał, że to, czy poprawiony system „Fregego lub też «teoria mnogości» p. Zermela doprowadzi kiedykolwiek do sprzeczności, jest kwestią najzupełniej obojętną z punktu widzenia stanów zwróconej ku rzeczywistości udręki intelektualnej, płynących z nieodpartej intuicyjnej konieczności wierzenia w «prawdziwość» pewnych założeń oraz w «poprawność» pewnych rozumowań” (Leśniewski, 1927, s. 167). Jedynym wyjściem dla Leśniewskiego była metoda „rzeczywistego" rozwiązywania antynomii, polegająca na intuicyjnym podważaniu składających się na sprzeczność założeń lub rozumowań (Leśniewski, 1927).

Leśniewski na własną rękę starał się uniknąć antynomicznych rezultatów paradoksu Russella. W efekcie był przekonany, że pracuje nad zagadnieniami związanymi z fundamentami matematyki i opracowuje pojęcie zbioru, które mogłoby stać się podstawowym pojęciem matematyki. Z tego właśnie powodu jego główna praca nosi tytuł $O$ podstawach matematyki (por. Pietruszczak, 2005, s. 214).

W realizacji tego zadania nie chciał uciekać się do twierdzeń, które jego zdaniem sytuowały się w rażącym konflikcie z intuicjami ogółu, takich jak choćby obowiązujący w teorii mnogości nakaz rozróżniania przedmiotu od zbioru zawierającego ten przedmiot jako jedyny element (Leśniewski, 1916, s. 5). Był przy tym przekonany, że pojęcie zbioru, jakie opracował, pokrywa się z Cantorowskim i że inne zbiory - dystrybutywne - są tylko fantazją matematyków i po prostu nie istnieją.

Niektóre fragmenty pism Cantora rzeczywiście wspierały takie rozumienie; szczególnie te, w których mówi się o „przedmiotach oglądu” i ,łączeniu w całość":

Pod pojęciem «rozmaitości» czy «zbioru» rozumiem mianowicie ogólnie każdą wielość, która może być pomyślana jako jedność, tj. każdy ogół określonych elementów, które na mocy pewnego prawa mogą być złączone w jedną całość (...). Pod pojęciem «zbioru» rozumiemy każde zebranie $\mathrm{w}$ jedną całość $\mathrm{M}$ określonych, dobrze odróżnionych przedmiotów $m$ naszego oglądu czy naszych myśli (które nazywane są «elementami» M) (Cantor, 1895, za: Murawski, 2003, s. 175-176).

Leśniewski powoływał się na pierwszy fragment dla ukazania rzekomego związku jego własnych intuicji z intuicjami twórcy teorii mnogości i, aby nie pozostawić nieporozumień co do zakładanego sensu terminu ,zbiór”, podawał przykłady. I tak np. utwór muzyczny składa się z dźwięków, których 
jest zbiorem, podobnie jak i obraz, który składa się z takich a takich części, których zbiór stanowi (Leśniewski, 1927, s. 190). W efekcie prezentowane tu rozumienie zbioru odbiega od rozumienia obowiązującego w teorii mnogości, gdzie przyjmuje się, że do zbioru melodii należą tylko melodie, a nie tworzące je dźwięki; tak jak i do zbioru obrazów tylko obrazy, a nie tworzące je części. Leśniewski jednak stał przy swoich intuicjach i w zgodzie z nimi odczytywał Cantora.

Naturalne dla Leśniewskiego kolektywne pojęcie zbioru było konsekwencją jego przywiązania do intuicji i nominalistycznego nastawienia. Punktem wyjścia dla jego rozważań była „koncepcja klasy (resp. zbioru) pozwalająca twierdzić o każdej w ogóle klasie (resp. zbiorze) tych lub innych przedmiotów, że się «składa» z tych właśnie przedmiotów" (Leśniewski, 1927, s. 190). Pewien walor eksplanacyjny ma tu intuicyjne pojęcie 'kupy' wziętej w rozumieniu luźnego agregatu obiektów. Leśniewski był przekonany, że dzięki utartemu w języku potocznym sposobowi używania wyrazu 'kupa', może on „o 'kupie' jakichś a zawsze powiedzieć, że jest zbiorem p-tów $a$, o 'kupie’ zaś p-tów $a$, składającej się ze wszystkich $a$, że jest klasą p-tów a" (Leśniewski, 1927, s. 205). Przyjmowane przez Leśniewskiego pojęcia zbioru i klasy możemy schematycznie przedstawić w następujący sposób:

$x$ jest zbiorem F-ów wtw każda część $x$ ma część wspólną z jakimś F-em, będącym częścią $x$

$x$ jest klasą F-ów wtw każdy F jest częścią $x$ oraz każda część $x$ ma część wspólną z jakimś F-em

Pojęcie części użyte w powyższych definicjach dopuszcza, by obiekt był swoją własną częścią, i odpowiada używanemu przez Leśniewskiego pojęciu ingrediensa. Obecnie, w badaniach nad mereologią, powyżej zaprezentowane pojęcie klasy jest eksplikowane przez pojęcie sumy mereologicznej (por. Pietruszczak, 1997, s. 124).

W odniesieniu do tak scharakteryzowanego pojęcia zbioru (resp. klasy) jest prawdą, że jeśli jakiś przedmiot jest klasą jakichś obiektów $a$, to się z tych $a$ po prostu składa. Jednocześnie ,nic nie może się składać z czegoś, czego wcale nie ma" (Leśniewski, 1927, s. 196). Dlatego Leśniewski twierdził, że zbiór elementów będących F-ami, istnieje tylko wtedy, kiedy istnieje co najmniej jeden obiekt, który jest F-em. W jednej z wczesnych 
prac, dysponując intuicjami wyklarowanymi w zaprezentowanym wyżej pojęciu klasy, Leśniewski wykazywał, że każdy obiekt jest swoją własną częścią, a w konsekwencji, że nie ma pustych klas (Leśniewski, 1914). Aby klasa była pusta, musiałby nie mieć części, a to jest niemożliwe, gdyż każda jest swoją własną częścią. Zatem nie istnieje klasa, która nie byłaby własną częścią, i tym samym nie istnieje klasa klas niebędących własnymi częściami. Leśniewski wykazał więc, że w ramach systemu przyjmującego kolektywne pojęcie zbioru nie da się zrekonstruować paradoksu Russella.

Paradoks ten ujawnił się jednak na gruncie teorii zbiorów dystrybutywnych i tam należało szukać jego rozwiązania. Dotyczył bowiem zbiorów rozumianych jako zakresy nazw, a nie rozciągłe przedmioty. Jednak dystrybutywne rozumienie zbioru wraz z pojęciem zbioru pustego były dla Leśniewskiego skrajnie nieintuicyjne i niezgodne z podstawowym, naturalnym poglądem na rzeczywistość. Koncepcję klas pustych traktował jako „mitologiczną” (Leśniewski, 1927, s. 186). W jego opinii odkrycie antynomii Russella zdominowało myślenie i wyobraźnię najwybitniejszych matematyków, a efektem usilnych prób jej uniknięcia było oderwanie matematyki od historyczno-intuicyjnego podłoża.

Sprzyjało to zanikowi poczucia różnicy pomiędzy naukami matematycznymi, pojmowanymi jako teorie dedukcyjne, służące do ujęcia w prawa możliwie ścisłe różnorodnej rzeczywistości świata, a takimi niesprzecznymi systemami dedukcyjnymi, które zabezpieczają wprawdzie możność otrzymywania na ich gruncie obfitości wciąż nowych twierdzeń, odznaczają się jednak jednocześnie brakiem jakichkolwiek łączących je z rzeczywistością walorów intuicyjno-naukowych (Leśniewski, 1927, s. 166).

Już w przedmowie do pracy z 1916 roku Leśniewski pisał, że niektóre jego twierdzenia mogą wydać się nieintuicyjne myślicielom kontemplującym „wytworność pewnych konstrukcji teoretycznych” niezależnie od tego, czy konstrukcje te ,przyczyniają się w jakimkolwiek stopniu do ujęcia naukowego rzeczywistości, czy też służą tylko do usprawiedliwienia panujących w naszej epoce, a odznaczających się dużym stopniem bezwładności, matematycznych przyzwyczajeń" (Leśniewski, 1916, s. 5). Innymi słowy, starał się, aby twierdzenia, ,posiadając postać możliwie ścisłą, harmonizowały ze «zdrowym rozsądkiem»" (Leśniewski, 1916, s. 6) obowiązującym wszystkich. Tymczasem teorie szukające ugruntowania matematyki w logice 
stawały się opisem zgodnym jedynie ,z tymi «intuicjami» fachowych teoretyków mnogości, które wyszły z zaopatrzonej w aparat «wolnej twórczości» centryfugi matematycznych umysłów, zdemoralizowanych przez «oderwane od rzeczywistości» spekulacyjne konstrukcje" (Leśniewski, 1916, s. 6). Jego system podstaw matematyki miał być zatem opisem obiektywnej rzeczywistości, której pierwotne, intuicyjne charakterystyki miał zachować. Intuicje te dotyczyły kolektywnego rozumienia zbioru jako przedmiotu konkretnego i stanowiły zasadniczy element przekonań ontologicznych Leśniewskiego. Jego standardy naukowej rzetelności nie pozwalały mu podjąć się filozoficznego uzasadnienia i oceny jego intuicji, a te pełniły zasadniczą rolę w formowaniu się jego systemu:

„źródłem” psychicznym moich aksjomatów są moje „intu ic j e” [wyróżnienie w całym cytowanym fragmencie za oryginałem - A.Sz.], co znaczy po prostu, że w prawdziwość moich aksjomatów w i e r zę, d l a c z e g o zaś wierzę, powiedzieć nie umiem, nie znam się bowiem na teorii przyczynowości. (...) Nie umiem wcale odpowiedzieć na pytanie, jaka jest „wartość obiektywna” moich aksjomatów, ani na żadne inne podobne pytania, które zadają sobie przedstawiciele tak zwanej teorii poznania (Leśniewski, 1916, s. 6).

Co prawda Leśniewski z czasem odrzucił większość szczegółowych poglądów filozoficznych rozwijanych we wczesnych pracach, jednak podstawowe, i intuicyjne dla niego, nominalistyczne przekonania ogólnofilozoficzne wyostrzały się z czasem. Bardzo wcześnie dał wyraz tezie, że wyrażenia 'byt' lub 'byty' nie posiadają żadnego znaczenia, mimo że odnoszą się do wszystkiego (Leśniewski, 1911). Gdyby rzeczywiście słowo 'byt' konotowało cechę istnienia, ,można by definiować 'byt' jako 'to, co posiada cechę istnienia', czyli innymi słowy jako 'byt, który posiada cechę istnienia', powstałby więc w ten sposób nieunikniony regressus in infinitum" (Leśniewski, 1911, s. 332). Dlatego twierdził, że słowo 'byt' nie podlega definicji (Leśniewski, 1911).

Podobnie wypowiadał się o znaczeniu słowa 'przedmiot'. Wychodząc od zdań typu 'P jest P' pisał, że występujący w tych kontekstach termin 'P', czyli 'przedmiot' albo 'byt', ,żadnych cech nie współoznacza” (Leśniewski, 1912, s. 208). Z tego powodu ,wyrazu 'przedmiot' nie można wcale definiować, jak i wyrazu 'byt', albowiem nie ma żadnego wyrażenia, które by było wyrażeniem rodzajowym w stosunku do wyrazu 'przedmiot' jako 
wyrażenia gatunkowego (Leśniewski, 1912, s. 223). Zatem 'przedmiot' lub 'byt' może oznaczać każdorazowo tylko indywidualne obiekty.

Myśl ta znajduje swoje rozwinięcie w dowodzie tezy, że przedmioty ogólne nie istnieją (Leśniewski, 1913, s. 319-320). Dowód wychodzi od przyjęcia istnienia pewnego przedmiotu ogólnego, który posiada cechy łącznie reprezentowane przez wszystkie jego indywidualne egzemplifikacje $\mathrm{P}_{\mathrm{i}}$. Każda z tych egzemplifikacji $\mathrm{P}_{\mathrm{i}}$ posiada także co najmniej jedną cechę swoistą, której nie posiadają inne obiekty indywidualne - nazwijmy ją cechą $C_{i}$. Przedmiot ogólny nie posiada zatem cechy $C_{i}$. Posiada więc cechę nieposiadania $\mathrm{C}_{\mathrm{i}}-$ oznaczmy ją jako $\mathcal{O}_{\mathrm{i}}$. Jeżeli jednak jakiś przedmiot $\mathrm{P}_{\mathrm{i}}$ posiada $\mathrm{C}_{\mathrm{i}}$, to nie posiada $\supset_{\mathrm{i}}$. Zatem $\mathrm{\supset}_{\mathrm{i}}$ nie przynależy wszystkim egzemplifikacjom $\mathrm{P}$. W konsekwencji przedmiot ogólny nie posiada także $\supset_{\mathrm{i}}$, a jeśli tak, to posiada $\mathrm{C}_{\mathrm{i}}$. Ostatecznie, przedmiot ogólny posiada cechę $\mathcal{\supset}_{\mathrm{i}}$ wtedy, kiedy posiada cechę $\mathrm{C}_{\mathrm{i}}$, co jest jawną sprzecznością, biorąc pod uwagę, że obie cechy są wzajem sprzeczne. Wskutek tego Leśniewski odrzucał istnienie powszechników.

Ten wczesny dowód czynił użytek z pojęcia cechy. Z czasem jednak Leśniewski ostatecznie odrzucił założenie o istnieniu cech (Leśniewski, 1927, s. 183), a powyższy dowód zastąpił formalnym dowodem założeniowym.

Należy także zauważyć, że Leśniewski przyjmował specyficzne pojęcie metafizyki jako teorii filozoficznej. Zdania o, ,wszystkich w ogóle przedmiotach" nazywał zdaniami metafizycznymi resp. ontologicznymi (Leśniewski, 1913, s. 316), natomiast system takich prawdziwych zdań o wszystkich przedmiotach nazywał metafizyką (Leśniewski, 1912).

Metafizyka pojmowana jako system zdań prawdziwych o wszystkich przedmiotach nie jest systemem zdań o przedmiotach ogólnych. „Zdania o przedmiotach 'ogólnych', które się rzekomo przeciwstawiają przedmiotom ‘indywidualnym' nie mogą być zdaniami metafizycznymi, nie dotyczą bowiem przedmiotów indywidualnych, a tym samym nie są zdaniami o wszystkich w ogóle przedmiotach" (Leśniewski, 1913, s. 318) - w istocie nie są zdaniami o żadnych przedmiotach, ponieważ Leśniewski nie przyjmował istnienia przedmiotów ogólnych. W konsekwencji, zdania metafizyki dotyczą tylko przedmiotów indywidualnych.

Polemizując z Łukasiewiczem, Leśniewski (1912) twierdził, że zdania kategoryczne typu 'Każde A jest B' „dotyczące wszystkich przedmiotów w ogóle, nie dają się ujmować w formę okresów warunkowych” (Lesniewski, 
1912, s. 211) - 'Jeśli coś jest A, to jest B'. Według Leśniewskiego to ostatnie zdanie jest równoznaczne ze zdaniem: 'jeśli coś ma cechy A, to ma też cechy B'. 'Coś' znaczy tyle co przedmiot, a zatem w konkretnym przypadku, w którym za A podstawimy słowo 'przedmiot' (P) otrzymujemy zdanie: 'Jeśli przedmiot ma cechy P, to ma też cechy B'. Jednak, jak zauważyliśmy już wyżej, P nie współoznacza żadnych cech. Dlatego nie istnieje przedmiot mający cechy P i mający cechy B. Jednak zdanie 'Każde P jest B' stwierdza, że każdy przedmiot posiada cechy B. Jest zatem możliwe, by zdanie kategoryczne było prawdziwe, a zdanie hipotetyczne - nie. $Z$ tego właśnie powodu metafizyka daje się skonstruować jedynie jako system zdań kategorycznych (Leśniewski, 1912).

Specyficzna wizja metafizyki resp. ontologii, wyłaniająca się z powyższego szkicu, zdaje się stać za niedostrzeganiem przez Leśniewskiego metafizycznego/ontologicznego wymiaru jego własnego systemu. Przy specyficznie wąskim rozumieniu metafizyki, mereologia mogła wydawać się Leśniewskiemu niczym więcej jak teorią zbiorów. Jednak właściwe mereologii pojęcie zbioru kolektywnego wyraża intuicje, które wiążemy ze złożonymi przedmiotami konkretnymi, dostępnymi w naszym powszednim, „życiowym” doświadczeniu. Inne typy przedmiotów pozostawały albo poza obszarem refleksji, albo zostały przez Leśniewskiego wprost odrzucone. Rozważane na gruncie mereologii pojęcie przedmiotu dotyczy więc przedmiotu w najogólniejszym sensie. Gdyby system ów rzeczywiście spełniał pokładane w nim nadzieje ufundowania matematyki, nauka ta stałaby się metafizyką, a mereologia grałaby rolę ontologicznej teorii przedmiotu.

\section{Witkiewicz wobec mereologii}

Witkiewicz sądził, że zadaniem ontologii jest opis bytu uzyskany poprzez „uzgadnianie koniecznych poglądów i ujmowanie ich w poglądzie jednolitym”. Ze względu na wymóg konieczności przyjmowanych założeń uważał, że ufundowana na arbitralnie wybranych aksjomatach ,logistyka jako taka (...) nie ma tu nic do powiedzenia. A jeśli ma, to (...) jest nowym systemem ontologii, i jako taka powinna bez maski wystąpić" (Witkiewicz, 2014c, s. 182). Dlatego też był skłonny postrzegać mereologię jako metafizykę vel ontologiczną teorię przedmiotu. Jej tezy były dlań obciążone ontologicznymi konsekwencjami dotyczącymi natury dziedziny przedmiotowej. 
Przekonanie takie nie jest bezzasadne. Mereologia została oparta na podstawach empirycznych, wywiedzionych z pewnej ograniczonej perspektywy poznawczej i jest systemem o naturze pozalogicznej (Woleński, 1989, s. 155). Obecnie istnieje rosnąca zgoda co do tego, że mereologia jest teorią, lub nawet grupą teorii, których tezy nie tyle odzwierciedlają cechy relacji części do całości, co raczej naturę przedmiotów (bytów), do których są stosowane (Gruszczyński, Varzi, 2015, s. 413). Poszczególne systemy mereologiczne mogą być postrzegane jako ontologie rożnych dziedzin szczegółowych, tj. ich ogólny, całościowy opis ze względu na przyjmowaną w tych teoriach konceptualizację relacji „bycia częścią”. Ponadto przyznaje się, że relacja „bycia częścią” może być aplikowana do badań nad całym spektrum dziedzin, w których może, ale nie musi przyjmować takich cech, jakie przypisał jej Leśniewski. Aksjomaty i tezy mereologii są przygodnie prawdziwe w zależności od dziedziny. Bardzo dużej wagi nabiera zatem pytanie o to, jakiej dziedziny wymagają. Pytanie o naturę dziedziny i jej przedmiotów jest zaś pytaniem z obszaru metafizyki.

Teoria metafizyczna Witkiewicza była pomyślana jako teoretyczny model rzeczywistości. Witkacy wierzył, że jego teoria nie tylko stosuje się do rzeczywistości, ale też adekwatnie opisuje jej naturę. Widzieliśmy, że Leśniewski także dążył do zachowania intuicji związanych z przedmiotami codziennego doświadczenia. Leżały one u podstaw zasadniczych pojęć i twierdzeń mereologii. Witkiewicz mógł więc postrzegać mereologię jako konkurencyjną ogólną teorię ontologiczną; konkurencyjny model teoretyczny tej samej dziedziny. Szczególnie, że w ontologii Witkiewicza indywiduum, podobnie jak klasa mereologiczna, jest bytem złożonym. Witkiewicz postulował, że dziedzinę jego teorii tworzą psychofizyczne indywidua rozumiane jako osobne monady posiadające zarówno rozciągłość samą dla siebie (ciało), jak i trwanie samo dla siebie (świadomość) (Witkiewicz, 2002c). Używany przez Kotarbińskiego termin 'osobnik' oddaje te dwie składowe sensu pojęcia monady. Osobniki takie są złożonymi i funkcjonalnie zorganizowanymi kompleksami (nagromadzeniami) analogicznych indywiduów niższych rzędów wielkości.

Czy wobec tego agregacyjnego rozumienia monady można postawić hipotezę, że mereologia jest zbiorem twierdzeń o monadach, oraz że monada danego rzędu wielkości jest klasą mereologiczną, której częściami są 
monady niższego rzędu wielkości (Kościuszko, 2005)? W myśl tej hipotezy mereologia mogłaby być formalno-logicznym modelem ontologii ogólnej. Istnieją jednak mocne kontrargumenty świadczące przeciwko tej tezie. Przyjmując, że monady są bytami dla siebie, posiadającymi zarówno ciało jak i świadomość, niektóre tezy mereologii zastosowane do monad stają się problematyczne w związku z interpretacją świadomości w terminach mereologicznie rozumianej części. Otrzymują one bowiem następujące interpretacje:

i) Jeżeli $\mathrm{P}$ jest częścią świadomości $\mathrm{P}_{1}$ i $\mathrm{P}_{1}$ jest także częścią świadomości $\mathrm{P}_{2}$, to $\mathrm{P}$ jest także częścią świadomości $\mathrm{P}_{2}$.

ii) Jeżeli P jest świadomością, to P jest mnogością świadomości.

iii) Świadomość $\mathrm{x}$ jest klasą świadomości $\mathrm{P}$ wtw każda świadomość $P$ jest częścią $x$, oraz każda część x ma część wspólną z jakąś świadomością $\mathrm{P}$.

Tezy te opisują świadomość jako poddającą się kompozycji. Jest wysoce wątpliwe, by kompozycyjność była własnością przynależną świadomości. Stanowi ona istotny problem dla wszystkich koncepcji zmuszonych rozważać kumulatywny rozwój świadomości indywidualnych, takich jak np. teorie panpsychistyczne (por. Goff, 2006, 2009; Bruntrup, Jaskolla, 2016). Tę problematyczną własność świadomości dostrzegł już James:

Weź zdanie złożone z 12 słów i powierz każde z nich jednej z 12 osób. Potem ustaw je w szeregu albo ściśnij w zwartą grupę, niech każdy pomyśli o powierzonym mu słowie tak intensywnie jak tylko może; nigdzie nie wystąpi świadomość całego zdania. (...) Poszczególne umysły nie scalają się w umysł wyższej złożoności (James, 1890, s. 160).

James doszedł do wniosku, że teza o kompozycyjności ,jest z tego powodu nie do utrzymania" (James, 1909, s. 207). Witkiewicz jednak tezy tej nigdzie nie postulował. Używając pojęcia trwania dla siebie, terminologicznego odpowiednika świadomości, pisał wprost, że „trwania (...) są zupełnie oddzielne (disparat) i jako takie nie mogą na siebie oddziaływać” (Witkiewicz, 2002c, s. 192). Można się zastanawiać, czy jego koncepcja nieskończoności synchronicznego istnienia podzielonego na rzędy wielkości 
pozwala mu uniknąć problemu kompozycyjności - być może była efektem prób jego ominięcia ${ }^{1}$.

Teza (iii) jest interpretacją definicji klasy (sumy) mereologicznej. (iii) jest równoważna stwierdzeniu, że istnieje jedna świadomość, której częściami są wszystkie świadomości. Witkiewicz jednak nie postulował tak mocnej tezy. Jego system był systemem ateistycznym, natomiast teza (iii) wymaga, aby w świecie istniała zupełna świadomość lub jeden, obejmujący wszystko, psychofizyczny byt. Teza (iii) jest także sprzeczna z postulatem Witkiewicza mówiącym, że pojęcie istnienia implikuje pojęcie wielości; gdyby jeden z elementów istnienia był nieograniczony, wtedy „nie ma już miejsca dla innych elementów: jest tylko ten jeden jedyny element, czyli Absolutna Nicość" (Witkiewicz, 2002c, s. 165).

Założenie, że mereologia jest „,zbiorem twierdzeń o monadach” (Kościuszko, 2005, s. 40), że system mereologii jest modelem systemu ontologii ogólnej Witkiewicza, możliwe jest tylko wtedy, kiedy osobnika traktujemy jedynie jako rozciągły obiekt - przedmiot; i dodatkowo godzimy się na konsekwencje wynikłe z definicji sumy mereologicznej. Jednak powyższe warunki, podobnie jak wspomniane we wstępie sugestie Kotarbińskiego, eliminują elementy swoiste systemu Witkacego. W efekcie takiego zabiegu otrzymujemy niekontrowersyjny zbiór twierdzeń o przedmiotach materialnych, który nie wyraża specyfiki ontologicznych poglądów Witkiewicza. Z tych względów mereologia nie może być teorią monad Witkiewicza. Czy jednak mogłaby być teoretycznym modelem przedmiotu niedoznającego (martwego) rozumianego na sposób przedstawiony w ontologii Witkiewicza?

W takim zastosowaniu mereologia miałaby pełnić rolę ontologicznej teorii rzeczy materialnej poglądu naturalnego nastawienia - miałaby być teoretycznym modelem martwego przedmiotu rozciągłego. Witkiewicz nie przypuszczał jednak, aby taki przedmiot istniat w metafizycznie podstawowym tego słowa sensie. Przyznawał, że przedmiot w ścisłym znaczeniu to

1 Hipoteza mówiąca o tym, że Witkiewicz zetknął się z tym problemem, jest dość daleko idąca, jednak nie niedorzeczna. Z pewnością znał pisma Jamesa już przed wojną. Pytaniem pozostaje kwestia tego, co dokładnie czytał. W liście do Malinowskiego ze stycznia 1914 r. Witkiewicz pisze: „Bardzo bym Ci był wdzięczny za pragmatystów i Jamesa, i za adres księgarni, z której mógłbym takie rzeczy wypisać" (Witkiewicz, 2013, s. 303). Natomiast w liście z przełomu marca i kwietnia 1914 r. Witkiewicz dziękuje Malinowskiemu za książkę (Witkiewicz, 2013, s. 314) - być może właśnie tę, o którą prosił. 
„tzw. 'namacalny', 'solidny' (...) niezmienny przedmiot poglądu życiowego” (Witkiewicz, 2002c, s. 329), stał jednak na stanowisku, że to, „,co nazywamy przedmiotami materialnymi i naszym ciałem, możemy określić jako prawidłowe, tzn. pod pewnymi warunkami powtarzające się związki jakości” (Witkiewicz, 2002e, s. 134). Fundament bytowy tak pojętych przedmiotów stanowią zbiorowiska subatomowej wielkości psychofizycznych indywiduów. Owe zbiorowiska same pozbawione są świadomości. Witkiewicz określał je terminem rozciągłości niebędącej rozciągłością dla siebie. Ugruntowują one przedmiot, który, jako taki, jakim jest dla nas, nie istnieje w ścisłym tego słowa znaczeniu. Posiada jedynie fenomenalny status - jawi się nam tylko. W myśl omawianej teorii bytem w sobie jest jedynie byt dla siebie. Z tego też powodu pojęcie przedmiotu nie może wejść w korpus pierwotnych pojęć systemu ontologii (Witkiewicz, 2002d, s. 115). Jego desygnat jest pochodny bytowo od Istnienia Poszczególnego - bytu dla siebie, monady.

Mereologia mogłaby być teorią tak właśnie pojętego przedmiotu martwego pod warunkiem, że jej tezy nie wykluczałyby się z tezami systemu ontologii Witkacego. Tak jednak nie jest. Witkiewicz co prawda twierdzi, że każdy przedmiot jest względnie stałym, prawidłowym następstwem jakości, odrzuca jednak tezę, że każde prawidłowe następstwo jakości jest przedmiotem (Witkiewicz, 2002c, s. 329).

Witkiewicz odrzuca zatem tezę będącą konsekwencją mereologii Leśniewskiego. Z definicji sumy wynika bowiem, że dla dowolnych obiektów $\mathrm{F}$ istnieje przedmiot $x$ będący ich sumą. Zatem sumą mereologiczną pary przedmiotów, takich jak np. Rysy i Wisła, będzie przedmiot, którego częściami będą Rysy, Wisła oraz - z racji przechodniości relacji części - także części Rysów i Wisły. Przyjmując, że przedmiot to prawidłowe następstwo jakości, widzimy, że jeśli dla dowolnych dwóch przedmiotów istnieje przedmiot będący ich sumą, to dowolne dwa prawidłowe zespoły jakości wyznaczają przedmiot. Ta własność sumy mereologicznej jest niezgodna z przyjmowaną przez Witkiewicza tezą, że nie każde prawidłowe następstwo jakości jest przedmiotem. Zatem, o ile chodzi o system Witkiewicza, tezy mereologii nie są prawdziwe ani w odniesieniu do psychofizycznych monad, ani w odniesieniu do fenomenalnie rozumianego przedmiotu.

Z przywołanych wyżej powodów tezę o mereologii jako o formalno-logicznej teorii psychofizycznych monad należy odrzucić. Witkiewicz diagnozował, że mereologia zastosowana do dziedziny przedmiotowej, jaką jest rzeczywistość świata naszego doświadczenia, przykrawa jej ontologiczną 
strukturę do swego języka i nie pozostawia miejsca na istotne własności tego świata.

Witkiewicz dostrzegał, że nawet, ,najprostsze rzeczywiste stany rzeczy, jakie napotykamy, są złożone i wykazują istnienie momentów niesamodzielnych" (Witkiewicz, 2014e, s. 497). Był jednak przekonany, że nie każdy typ stosunku zachodzi w obrębie dowolnego typu przedmiotu. Był świadom faktu, że istnieją „,różnice jakościowe niesprowadzalne między różnymi przedmiotami i stosunkami i stosunek całości i części nie jest od tego wolny" (Witkiewicz, 2002a, s. 406). Rozumiał, że w rzeczywistości istnieje wiele różnych stosunków typu część-całość utrzymujących się między różnymi klasami bytów. Swoimi spostrzeżeniami wyprzedził współczesną refleksję dostrzegającą to zróżnicowanie (por. Mellor, 2006).

W szczególności twierdził, że świadomość i ciało nie stanowią czę$s ́ c i$ indywiduum. Wzajemną relację świadomości i rozciągłości opisywał w terminach momentów niesamodzielnych. To ostatnie pojęcie Witkiewicz zaczerpnął od Husserla. Uważał, iż mimo tego, że nierozdzielne i niesamodzielne, to stanowią one częściowe składniki całości, którą łącznie stanowią - jak barwa i kształt w doświadczeniu wzrokowym (Husserl, 2000, s. 286). Tak jak barwa i kształt, tak i ciało, i świadomość mogą być traktowane jako odrębne jedynie w abstrakcji (Husserl, 2000, s. 317; Witkiewicz, 2002c). Te momenty niesamodzielne jednak nie są tym samym, co części, tak jak i całość nie jest tym samym, co jedność. Wyodrębnienie momentów niesamodzielnych istnienia jako autonomicznych części pozwala postrzegać je jako wzajem niezależne. Jednak Witkiewicz neguje możliwość istnienia świadomości w oderwaniu od ciała. Z drugiej strony, każda rozciągłość pozbawiona świadomości siebie stanowi, w myśl jego poglądów, układ indywidualnych, ucieleśnionych świadomości, leżący u podłoża fenomenalnie danego przedmiotu. $Z$ tego powodu utożsamienie momentów niesamodzielnych i części prowadzi, zdaniem Witkacego, do zniesienia różnicy między bytem samym dla siebie (trwaniem samym dla siebie) a rzeczą - przedmiotem zjawiskowym (Witkiewicz, 2014e, s. 497).

Powyższe wnioski zestrojone są z oceną nauki wchodzącej w rolę metafizyki. Witkiewicz sądził, że nie można od nauki, czyli względnie pewnej wiedzy o zjawiskach - a na tym są oparte nasze intuicje dotyczące relacji części do całości - oczekiwać, by stała się wiedzą o ogólnej naturze bytu (Dombrowski, 2011, s. 119-134). Zarówno Witkiewicz, jak i Leśniewski mieli zgodne przeświadczenie, że to w poglądzie przednaukowym filozofia 
i nauka uzyskują podstawowe intuicje dotyczące natury istnienia. Jednak przednaukowy światopogląd nie jest jeszcze metafizyką. Tymczasem, wraz z wyniesieniem do rangi podstaw matematyki czy teorii przedmiotu, uzyskuje on walor ogólności, na który nie zasługuje bez dodatkowych świadectw teoretycznych. W jednej z prac Witkiewicz zauważa z wyrzutem, że to właśnie pod wpływem pojęć poglądu naturalnego nastawienia „tworzą niektórzy filozofowie gmachy zadziwiające swoją konstrukcją w wyższych piętrach swych, a stojące na nieproporcjonalnie nikłych fundamentach" (Witkiewicz, 2014e, s. 504). W świetle powyższych rozważań trudno nie odnieść tego fragmentu do systemu Leśniewskiego.

\section{Zakończenie}

Krytyka uniwersalistycznych roszczeń logistyki znajduje ugruntowanie w Witkiewiczowskim rozumieniu roli filozofii, vel metafizyki, pojętej jako ontologia ogólna, czyli ogólna nauka o koniecznych prawach istnienia. W ramach jego projektu zadaniem filozofii jest dojście „do jednoznacznego, koniecznie takiego a nie innego punktu wyjścia: pojęcia (względnie: pojęć) pierwotnego i pierwotnych z niego wynikających twierdzeń. Następnie ułożenie kompletnej listy pojęć pierwotnych, niedefiniowalnych; określenie pierwotnych poglądów koniecznych i wyznaczenie ich wzajemnych stosunków (...) i ujęcie ich we wspólny system (...)" (Witkiewicz, 2014a, s. 83-84). Oczywiście Witkacy był przekonany, że to jego teoria dochodzi do takiego „punktu wyjścia” i w kolejnym kroku poprawnie opisuje rzeczywistość. Dlatego sądził, że tezy jego systemu są spełnione w świecie rzeczywistym. $\mathrm{Z}$ tego powodu rzeczywistość nie odpowiada modelowi mereologii. Jego zdaniem mereologia stawia arbitralne założenia i uniwersalizuje pewne rozumienie przedmiotu, które zostało przyjęte bez należytego zrozumienia natury dziedziny przedmiotowej.

Mimo tego, że obaj autorzy byli nominalistami - odrzucali istnienie pojęć jako ekstensji zbiorów i nie uznawali istnienia powszechników, zaś byt rozumieli jako całość złożoną z mnogości konkretnych indywiduów - to jednak dzieliły ich nieprzekraczalne różnice na poziomie szczegółowym. Przede wszystkim Witkiewicza interesował problem psychofizyczny. Dla jego rozwiązania postulował istnienie mnogości psychofizycznych indywidualnych osobników, łączących w nieredukowalny sposób cechy 
mentalne i fizyczne. Leśniewskiego zaś frapowała natura samej mnogości; naturę jej elementów legitymizował codziennymi intuicjami; w temacie teorii poznania nie wypowiadał się. Witkiewicz podjął się rekonstrukcji świata w terminach owych osobników (monad), Leśniewski - konstrukcji mnogości w terminach przedmiotu fizycznego. W systemie Witkiewicza przedmioty mają status czysto fenomenalny, abstrakcyjny, zależny. Konkretami zaś są monady i układy monad, których zjawiskami są właśnie przedmioty. Układy mają części, ale poniżej pewnego poziomu owe części nie są tym samym, czym są dla Leśniewskiego - kolejnymi przedmiotami. W ontologii Witkiewicza są to samoświadome indywidua. Dla ich skupisk tezy mereologii nie obowiązują.

\section{Bibliografia}

Bruntrup, L., Jaskolla, G. (red.) (2016). Panpychism. Oxford: Oxford University Press.

Dombrowski, M. (2011). Filozofia i nauka: trudne związi. Toruń: Wydawnictwo Naukowe UMK.

Goff, P. (2006). Experiences Don't Sum. Journal of Consciousness Studies, 13 (10-11), 53-61.

Goff, P. (2009). Can the Panpsychist Get around the Combination Problem? W: D. Skrbina (red.), Mind that Abides: Panpsychism in the New Millennium (s. 129-135). Amsterdam: John Benjamins Publishng Company.

Grygianiec, M. (2000). Leśniewski przeciw powszechnikom. Filozofia Nauki, 8(3), $110-125$.

Gruszczyński, R., Varzi, A. (2015). Mereology Then and Now. Logic and Logical Philosophy, 24, 409-425. DOI: http://dx.doi.org/10.12775/LLP.2015.024.

Husserl, E. (2000). Badania Logiczne. T. 2. Tłum. J. Sidorek. Warszawa: Wydawnictwo Naukowe PWN.

James, W. (1890). The Principles of Psychology. New York: Henry Holt and Company.

James, W. (1909). A Pluralistic Universe, Hibbert Lectures to Manchester College on the Present Situation in Philosophy. London: Longmans, Green \& Co.

Kościuszko, K. (2005). O niektórych motywach teoriomnogowościowo-logicznych w filozofii Witkiewicza. Modus. Trochę ilustrowany magazyn ogólnohumanistyczny o subtelnym zabarwieniu filozoficznym, 7 (3), 38-43. 
Kotarbiński, T. (2002). Witkiewicz Stanisław Ignacy: „Pojęcia i twierdzenia implikowane przez pojęcie Istnienia”. W: S.I. Witkiewicz, Dzieła zebrane. T. 13. Oprac. B. Michalski (s. 387-403). Warszawa: PIW.

Leśniewski, S. (1911). Przyczynek do analizy zdań egzystencjalnych. Przegląd Filozoficzny, 14, 330-345.

Leśniewski, S. (1912). Próba dowodu ontologicznej zasady sprzeczności. Przegląd Filozoficzny, 15, 202-226.

Leśniewski, S. (1913). Krytyka logicznej zasady wyłączonego środka. Przegląd Filozoficzny, 16, 315-352.

Leśniewski, S. (1914). Czy klasa klas niepodporządkowanych sobie, jest podporządkowana sobie? Przegląd Filozoficzny, 17, 63-75.

Leśniewski, S. (1916). Podstawy ogólnej teoryi mnogości. I. Prace Polskiego Koła Naukowego w Moskwie. Sekcja Matematyczno-Przyrodnicza, 2, 1-42.

Leśniewski, S. (1927). O podstawach matematyki. Rozdział I-III. Przegląd Filozoficzny, 30, 164-206.

Leśniewski, S. (1928). O podstawach matematyki. Rozdział IV. Przegląd Filozoficzny, 31, 261-291.

Leśniewski, S. (1929). O podstawach matematyki. Rozdział V. Przegląd Filozoficzny, 32, 60-101.

Leśniewski, S. (1930). O podstawach matematyki Rozdział VI-IX. Przegląd Filozoficzny, 33, 77-105.

Leśniewski, S. (1931). O podstawach matematyki. Rozdział X-XI. Przegląd Filozoficzny, 34, 142- 170 .

Lindenbaum, A., Tarski, A. (1926). Komunikat o badaniach z zakresu teorji mnogości. Sprawozdania z Posiedzeń Towarzystwa Naukowego Warszawskiego Wydziat III, 7-9, 299-330.

Łukasiewicz, J. (1933). Logistyka a filozofja. Przegląd Filozoficzny, 39, 115-131.

Mellor, D.H. (2006). Wholes and Parts: The Limits of Composition. South African Journal of Philosophy, 25 (2), 138-145. DOI: http://dx.doi.org/10.4314/ sajpem.v25i2.31440.

Morszczyński, W. (1980). Logika a ontologia w systemie filozoficznym Stanisława Ignacego Witkiewicza. W: E. Żarnecka-Biały (red.), Logika i jej nauczanie $w$ dziejach Uniwersytetu Jagiellońskiego. Kraków: Uniwersytet Jagielloński. 
Murawski, R. (2003). Filozofia matematyki. Antologia tekstów klasycznych. Poznań: Wydawnictwo Naukowe UAM.

Pietruszczak, A. (1997). Co to jest mereologia. W: C. Gorzka, R. Jadczak (red.), Studia z filozofii i logiki. Ksiega pamiatkowa $w$ darze Profesorowi Leonowi Gumańskiemu (s. 115-128). Toruń: Wydawnictwo UMK.

Pietruszczak, A. (2005). Pieces of Mereology. Logic and Logical Philosophy, 14, 211-234. DOI: http://dx.doi.org/10.12775/LLP.2005.014.

Urbaniak, R. (2008). Leśniewski's Systems of Logic and Mereology; History and Re-evaluation. Pobrane z: http://dspace.ucalgary.ca/bitstream/1880/46697/1/ Urbaniak_2008.pdf.

Urbaniak, R. (2015). Stanisław Leśniewski: Rethinking the Philosophy of Mathematics. European Review, 23 (1), 125-138. DOI: https://doi.org/10.1017/ S1062798714000611.

Witkiewicz, S.I. (2002a). Odpowiedź Tadeuszowi Kotarbińskiemu. W: S.I. Witkiewicz, Dzieła zebrane. T. 13. Oprac. B. Michalski (s. 404-417). Warszawa: PIW.

Witkiewicz, S.I. (2002b). O dwóch typach filozofów. W: S.I. Witkiewicz, Dzieła zebrane. T. 13. Oprac. B. Michalski (s. 56-70). Warszawa: PIW.

Witkiewicz, S.I. (2002c). Pojęcia i twierdzenia implikowane przez pojęcie istnienia. W: S.I. Witkiewicz, Dzieła zebrane. T. 13. Oprac. B. Michalski (s. 147-384). Warszawa: PIW.

Witkiewicz, S.I. (2002d). Spór o monadyzm. Dwugłos polemiczny z Janem Leszczyńskim. S.I. Witkiewicz, Dzieła zebrane. T. 16. Oprac. B. Michalski (s. 5-357). Warszawa: PIW.

Witkiewicz, S.I. (2002e). Stosunek wzajemny nauki i filozofii. W: S.I. Witkiewicz, Dzieła zebrane. T. 13. Oprac. B. Michalski (s. 120-146). Warszawa: PIW.

Witkiewicz, S.I. (2013). Stanisław Ignacy Witkiewicz. Listy I. W: S.I. Witkiewicz, Dzieła zebrane. T. 17. Oprac. T. Pawlak (s. 7-1092). Warszawa: PIW.

Witkiewicz, S.I. (2014a). Nauki ścisłe a filozofia. W: S.I. Witkiewicz, Dzieła zebrane. T. 15. Oprac. M. Dombrowski, M. Bizior-Dombrowska (s. 68-93). Warszawa: PIW.

Witkiewicz, S.I. (2014b). O Logice. W: S.I. Witkiewicz, Dzieła zebrane. T. 15. Oprac. M. Dombrowski, M. Bizior-Dombrowska (s. 482-493). Warszawa: PIW.

Witkiewicz, S.I. (2014c). O Logistyce (zwierzenia laika). W: S.I. Witkiewicz, Dzieła zebrane. T. 15. Oprac. M. Dombrowski, M. Bizior-Dombrowska (s. 161-189). Warszawa: PIW. 
Witkiewicz, S.I. (2014d). O ontologicznej beznadziejności logiki, fizykalizmu i pseudonaukowego monizmu w ogóle i o perspektywach koncepcji monadystycznej. W: S.I. Witkiewicz, Dzieła zebrane. T. 15. Oprac. M. Dombrowski, M. Bizior-Dombrowska (s. 347-363). Warszawa: PIW.

Witkiewicz, S.I. (2014e). Traktat o Bycie samym w sobie i dla siebie. W: S.I. Witkiewicz, Dzieła zebrane. T. 15. Oprac. M. Dombrowski, M. Bizior-Dombrowska (s. 494-569). Warszawa: PIW.

Woleński, J. (1989). Logic and Philosophy in the Lvov-Warsaw School. Dordrecht: Kluwer Academic Publishers.

\section{HAVE MONADS ANY PARTS? \\ WITKIEWICZ ON MEREOLOGY AS ONTOLOGY}

\section{Summary}

This paper reconstructs Stanisław Ignacy Witkiewicz's understanding of logic, accentuating the differences in his evaluation of logic and systems of 'logistics'. Leśniewski's theory of collective sets (mereology) exemplifies logistics as understood by Witkiewicz. I present an outline of Leśniewski's nominalism, which entails a belief in a non-abstract nature of sets. I focus on these features of mereology that could have led Witkiewicz to interpreting it as an ontological system. Witkacy (Witkiewicz's penname) was skeptical of the usefulness of formal systems (or logistics), and of mereology in particular, for the purposes of designing a unified ontological system describing essential properties of objects (the world). According to Witkiewicz, such formal systems assumed the role of ontology but severely lacked in philosophical justification. I argue that regardless of his nominalism and corporeal conception of individuals, mereology cannot be considered a formal theory of Witkiewicz's monads. 